\title{
The correlation between thermal comfort in buildings and fashion products
}

\author{
Aline Giesel ${ }^{\mathrm{a}}$, Patrícia de Mello Souza ${ }^{\mathrm{b}}$ \\ ${ }^{a}$ Departamento de Design, Universidade Estadual de Londrina, UEL, alinegiesel@gmail.com, Rodovia \\ Celso Garcia Cid km 380, 5543 33714479, Londrina, PR, Brasil \\ ${ }^{b}$ Departamento de Design, Universidade Estadual de Londrina, UEL, patmel@sercomtel.com.br; \\ PPGDesign, Universidade Estadual Paulista, UNESP, Av. Eng ${ }^{\circ}$. Luiz Edmundo Carrijo Coube 14-01, \\ 551431036057, Bauru, SP, Brasil
}

\begin{abstract}
This article is about thermal comfort in the wearable product. The research correlates fashion and architecture, in so far as it elects the brise soleil - an architectural element capable of regulating temperature and ventilation inside buildings - as a study referential, in trying to transpose and adapt its mechanisms to the wearable apparel.
\end{abstract}

Keywords: Fashion design, Pattern Making, Ergonomics, Thermal comfort, Architecture

\section{Introduction}

Architecture and fashion, in different scales, represent types of shelter, searching for balance among function, aesthetics and comfort. Clothing can be considered "as a package for the body or textile architecture in which each line has a meaning and manifests a specific taste localizing its time and space" [3]

Congruent points are observed between the fashion products' conception and the architectural project. Aspects that are relevant for the development of buildings, such as: The inhabitants' needs in relation to construction, terrain conditions and their surroundings, could be, in regards to fashion, compared to the importance of knowing the users' figure, demands and the environment in which they find themselves

Comfort is an interrelationship network which is connected to the characteristics of the subject, of the object and of the environment, in a specific context [5]. To develop an architectural project that aims for the user's thermal comfort, some aspects must be observed, such as sunlight orientation, the use of natural ventilation and front shading, among others [1]. Thus, it becomes possible to import the concept of thermal comfort from architecture to the field of fashion, establishing a dialog between the two fields of knowledge.

Mascarello [4] and Souza [6] reaffirm the importance of people's satisfaction in the environments in which they find themselves. Architecture is responsible for the creation of comfortable spaces, as well as fashion is responsible for the comfort of the user when it comes to clothing. In this sense, it is justifiable to establish a parallel between the architectural structures that grant thermal comfort in buildings and the resources used in the construction of the fashion product that directly interfere on the user's thermal comfort.

Comfort deals with convenience and wellbeing: Considering that clothing is the first habitat for the body - like a second skin - it directly affects the user's way and quality of life, interfering on their sensations and perceptions [6]. Architecture aims to harmonize constructions according to local weather and characteristics, turning the built spaces into comfortable spaces, using resources that favor natural lighting and ventilation.

Therefore, it's possible to glimpse the possibility of appropriating the resources used in architecture for the construction of a comfortable 
space in fashion clothing. Addressed here is the development of a textile mechanism capable of controlling the ventilation and temperature that affect the user's body in hotter days.

\section{Methodology and construction}

Initially, a detailed study about the brise soleil is conducted. Afterwards, the knowledge of the body's temperature control mechanisms is deepened. Finally, practical experimentations made possible by using three-dimensional pattern making enabled the study and transposition of the foreseen functions and mechanisms.

The brise soleil acts on the control and reduction of heat gain, and it is generally composed of parallel blades, external to the construction, whose placement can be vertical, horizontal or mixed, depending on the angle of sunlight incidence one desires to filter [2]. It is presented in fixed or movable forms. When movable, it allows the building's users to control the amount of sunlight entering the environment.

Regarding body anatomy, it is important to explain that when the environment's thermal conditions surpass certain limits, the thermo regulators are activated: in contact with high temperatures, the peripheral vasodilatation, which contributes to heat loss by ways of convection and radiation, is activated [4]. The sweat glands eccrine, which are distributed around the body's surface; and apocrine, which concentrate on the areas in and around the axillae, the genitals, the navel, the nipples and the ears - are responsible for the production and secretion of sweat. (Fig. 1).

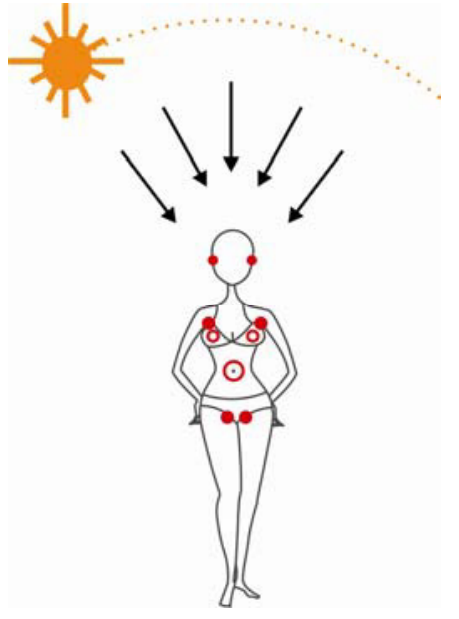

Fig. 1 - Concentration points of sweat glands. Incidence of sun rays in the health hazardous period. Source: Personal (2011).

The study of the aspects related to the control of temperature in both contexts, associated to the use of three-dimensional pattern making techniques during the development process, result in the conception of prototypes with flexible mechanisms (Fig. 2), which not only satisfy thermal comfort requirements, but also allow multiple configurations and instigate the user's interaction. The materials chosen to make the products - a $100 \%$ cotton cambric applied internally, and a blend of $98 \%$ cotton and $2 \%$ elastane in the upper part - help the heat swap between the environment and the garment, as well as giving the flexibility needed to the well functioning and effectiveness of the mechanisms.

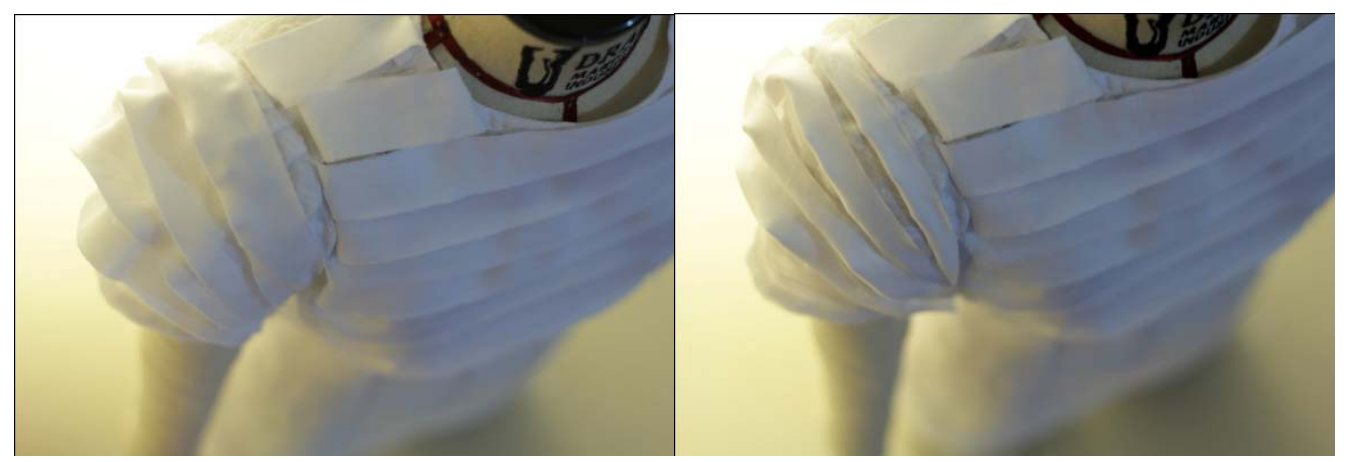

Fig.2 - Details of the mechanisms that promote ventilation: Closed and opened structures. Source: personal (2011) 


\section{Final Considerations}

The obtained results refer back to the discussion regarding the ergonomic aspects involved in the development of fashion products. Clothing can contribute to the maintenance of the body's thermal balance, be it by means of adequate materials, which employ the use of fabric with a higher rate of gaps, and fibers that provide better breathability, or by using pattern making that contemplates mechanisms capable of privileging ventilation in areas with higher concentrations of sweat glands, in addition to enabling the flexibility of the product's internal space. They also prove the contributions afforded by the dialog established between the different areas, in the sense of acquiring knowledge with potential to generate new ways of application.

\section{References}

[1] Corbioli, Nanci. Para esfriar o ambiente e o bolso. Projeto Design, 297,n.4, novembro, 2004. Disponível em:< http://www.arcoweb.com.br/tecnologia/conforto-termico- ar-condicionado-24-11-2004.html> Acesso em: 12 mai. 2011.

[2] Gutierrez, Grace Cristina Roel; Labaki, Lucila Chebel. Avaliação de desempenho térmico de três tipologias de brise-soleil fixo. In: ENCAC-ELACAC, 2005, Maceió, Anais...disponível em: www.arquitetura.ufmg.br/labcon/download.php?dir=arqui vos/\&file... Acesso: 5 de mar. de 2011.

[3] Martins, Suzana Barreto. Ergonomia e usabilidade: princípios para projeto de produto de moda. In: Congresso Brasileiro de Ergonomia, 14., 2006. Curitiba. Anais... Curitiba: ABERGO, 2006.

[4] Mascarello, Vera Lucia Dutra. Princípios bioclimáticos e princípios de arquitetura moderna : Evidências no edifício hospitalar. Dissertação (pós- graduação). Universidade Federal do Rio Grande do Sul, Porto Alegre. 2005.

[5] Silva, Lizandra. Aspectos teóricos do conforto sob o ponto de vista da ergonomia. In: Congresso Brasileiro de Ergonomia, 16., 2010, Rio de Janeiro. Anais... Rio de Janeiro: ABERGO, 2010.

[6] Souza, Patrícia de Mello. A Modelagem Tridimensional como Implemento do Processo de Desenvolvimento do Produto de Moda. Dissertação (Mestrado). Universidade Estadual Paulista, Bauru. 2006. 